\title{
Nilai - Nilai Personal Pembentuk Persepsi Dukungan Organisasi
}

\author{
Umi Anugerah Izzati ${ }^{1}$ \\ Program Studi Psikologi Universitas Negeri Surabaya \\ Fendy Suhariadi dan Cholichul Hadi \\ Fakultas Psikologi Universitas Airlangga Surabaya
}

\begin{abstract}
This study aims to determine the influence personal values to perceived organizational support to the Junior High School teacher. This research is a quantitative method. The subjects were high school teachers who work in the private Islamic Education Foundation in Surabaya. Measurement instrument used is the Quesioner of personal values and perceived organizational support quesioner. While data analysis techniques using multiple regression analysis. The results showed that of the top ten personal values, there are only three personal values that influence perceived organizational support that are security, conformity, tradition. This suggests that in order to improve the perceived organizational support needed teachers have personal value security who have safety, personal value conformity who have self-control, personal value tradition encouragement that violate social norms, respect and acceptance of one's will of cultural and religious affiliations.
\end{abstract}

Keywords: Security, Conformity, Tradition And Perceived Organizational Support.

\begin{abstract}
Abstrak: Penelitian ini bertujuan untuk mengetahui pengaruh nilai-nilai personal terhadap persepsi dukungan organisasi pada guru Sekolah Menengah Pertama. Penelitian ini mennggunakan metode kuantitatif. Subyek penelitian ini adalah guru-guru sekolah menengah pertama swasta yang bekerja dalam Yayasan Pendidikan Islam di Surabaya. Instrumen pengukuran yang dipakai adalah skala nilai-nilai personal dan skala persepsi dukungan organisasi. Sementara teknik analisis data menggunakan analisis multiple regresi. Hasil penelitian menunjukkan bahwa dari sepuluh nilainilai personal, hanya ada tiga nilai-nilai personal yang mempengaruhi persepsi dukungan organisasi yaitu nilai personal security, nilai personal conformity, dan nilai personal tradition. Hal ini menunjukkan bahwa untuk meningkatkan persepsi dukungan organisasi dibutuhkan guru-guru yang memiliki nilai personal security yang menekankan pada rasa aman, nilai personal conformity yang memiliki pengendalian diri terhadap kemauan dan dorongan yang dianggap melanggar norma-norma sosial yang berlaku, nilai personal tradition adanya rasa hormat dan penerimaan seseorang akan budaya dan agama yang dianut.
\end{abstract}

Kata kunci: Security, Conformity, Tradition Dan Persepsi Dukungan Organisasi.

\section{PENDAHULUAN}

Pada organisasi sekolah guru memiliki peranan yang penting sebagai salah satu sumber daya manusia yang menentukan kelangsungan maupun tercapainya tujuan organisasi. Kelangsungan maupun pencapaian tujuan organisasi sekolah dapat tercapai salah satunya dengan memberikan perhatian pada guru-gurunya. Perhatian terhadap guru-guru dapat dilakukan melalui cara memberikan dukungan terhadap guru-

\footnotetext{
${ }^{1)}$ Korespondensi tentang artikel ini dapat dialamatkan kepada Umi Anugerah Izzati melalui e-mail: umianugerah@gmail.com.
} 
guru yang bekerja di sekolah. Pentingnya dampak dukungan organisasi bagi kelangsungan maupun tujuan organisasi dapat dilihat pada beberapa penelitian. Penelitian yang dilakukan para ahli menunjukkan bahwa persepsi dukungan organisasi memiliki dampak terhadap komitmen afektif (Klien,dkk 2009), kesejahteraan psikologis (Diener, dkk 2004), kepercayaan (Shore,dkk 2006), organizational citizenship behaviors (Cropanzano \& Mitchell, 2005; Lavelle, 2007) dan kinerja (Byrne, 2008).

Penelitian yang telah dilakukan Byrne (2008) menunjukkan bahwa persepsi dukungan organisasi memiliki pengaruh terhadap kinerja karyawan. Karyawan yang mempersepsi dukungan organisasi secara baik akan mempengaruhi kinerjanya menjadi lebih optimal. Mengacu pada beberapa penelitian mengenai dampak yang timbul salah satunya adalah kinerja maka bisa dianalogikan bahwa guru-guru sebagai sumber daya manusia pada organisasi sekolah yang mempersepsi mendapat dukungan organisasi sekolah dengan baik akan dapat mempengaruhi kinerjanya menjadi baik.

Rhoades \& Eisenberger (2002) mengemukakan bahwa persepsi dukungan organisasi adalah persepsi karyawan tentang sejauhmana organsasi menghargai kontribusi dan peduli tentang kesejahteraan karyawan. Secara teoritis, karyawan yang mempersepsi dukungan organisasi yang kuat akan membuat karyawan merasa perlu untuk membalas perlakukan organisasi yang disukai dengan sikap dan perilakunya yang nantinya akan menguntungkan organisasi. Dukungan organisasi yang dipersepsikan mencerminkan adanya persepsi karyawan bahwa organisasi menghargai kontribusi dan peduli terhadap karyawan yang bekerja pada organisasi.

Menurut Rhoades dan Eisenberger (2002), pada persepsi dukungan organisasi ada beberapa hal yang perlu diperhatikan, diantaranya yaitu 1). Keadilan. Keadilan yang dimaksud adalah keadilan prosedural. Keadilan prosedural berkenaan dengan masalah keadilan mengenai cara-cara yang digunakan untuk mendistribusikan sumbersumber daya yang ada dalam organisasi; 2). Dukungan atasan. Karyawan memandang segala tindakan-tindakan yang dilakukan atasan sebagai perwujudan dari dukungan organisasi; (3) Penghargaan Organisasi dan Kondisi Kerja. Penghargaan yang dimaksud dapat berupa gaji dan promosi. Selain itu, adanya keamanan kerja memiliki arti bahwa perlu adanya kepastian bahwa organisasi akan tetap mempertahankan keanggotaan karyawan dimasa depan dan hal ini diharapkan akan menyebabkan tingginya dukungan organisasi yang dipersepsi karyawan.

Ada beberapa faktor yang mempengaruhi persepsi dukungan organisasi salah satunya adalah dengan memperhatikan karakteristik individu. Peneliti menggunakan landasan hasil penelitian Erdogan, dkk (2004) yang menunjukkan bahwa nilai-nilai personal yang sesuai dengan organisasi tempat individu bekerja merupakan antensenden dari persepsi dukungan organisasi. Sebelum individu memiliki kesesuaian nilai-nilai personal dengan nilai-nilai organisasi tempatnya bekerja maka perlu untuk diketahui nilai-nilai personal masing-masing individu yang bekerja pada suatu organisasi. Sejauh ini sepengetahuan peneliti belum ada penelitian yang membahas tentang nilai-nilai personal individu yang bekerja pada suatu organisasi yang dapat mempengaruhi persepsi dukungan organisasi, padahal nilai-nilai personal merupakan salah satu karakteristik personal yang penting untuk diperhatikan.

Schwartz (1992) mendeskripsikan nilai-nilai personal merupakan tujuan hidup yang berperan penting bagi kehidupan individu, mempengaruhi persepsi, melakukan justifikasi serta mengevaluasi perilaku. Nilainilai personal juga menempati posisi sentral 
dalam sistem kognitif individu dan untuk alasan ini nilai-nilai personal dapat mempengaruhi sikap kita, proses pengambilan keputusan, dan secara umum semua perilaku manusia. Sementara Schwartz dan Sagiv (1995) mengemukakan bahwa nilai-nilai personal yang bervariasi tergantung pada situasi yang ada, seberapa penting nilainilai personal berfungsi sebagai pedoman hidup individu. Nilai-nilai personal bisa berbeda satu sama lain karena tujuan hidup masing-masing individu bisa berbeda.

Schwartz (2012) menggambarkan sepuluh nilai-nilai personal terdiri dari:

1. Self Direction digambarkan sebagai individu yang memiliki pemikiran independen dalam bertindak, memilih, menciptakan, dan menjelajahi.

2. Stimulation digambarkan sebagai individu yang memiliki kegembiraan, kebaruan, dan tantangan dalam hidup.

3. Hedonism digambarkan sebagai individu yang senang memuaskan diri, menikmati hidup, dan memanjakan diri sendiri.

4. Security digambarkan sebagai individu yang mementingkan pada rasa aman khususnya dalam hal keselamatan, keselarasan, stabilitas diri, stabilitas kesehatan dan stabilitas hubungan.

5. Conformity digambarkan sebagai individu yang memiliki kemampuan dalam melakukan pengendalian diri yang baik sehingga mampu melakukan kontrol terhadap kemauan dan dorongan yang diluar kebiasaan secara khusus dalam hal ketaatan, sopan santun, kepatuhan dan dapat melakukan kontrol diri.

6. Tradition digambarkan sebagai individu yang memiliki penerimaan diri, penerimaan budaya atau agama, penerimaan adat istiadat atau tradisi dan rasa hormat pada orang lain.

7. Achievement digambarkan sebagai individu yang memiliki ambisi, ingin sukses, merasa mampu, dan berpengaruh.
8. Power digambarkan sebagai individu yang memiliki otoritas, kekayaan dan kekuasaan.

9. Benevolence digambarkan sebagai individu yang memiliki kebermanfaatan, jujur, memaafkan dan mementingkan pada persahabatan sejati.

10. Universalism digambarkan sebagai individu yang memiliki kehidupan spiritual, makna hidup, harmoni batin, tidak mudah terpengaruh dan merasa memiliki kesatuan dengan alam.

Penelitian ini ingin mengetahui nilainilai personal apa saja yang dapat mempengaruhi persepsi dukungan organisasi. Peneliti menganggap bahwa nilai-nilai personal penting untuk diperhatikan terutama pada lingkup organisasi sekolah. Walaupun tidak memiliki pengaruh langsung terhadap perilaku, nilai-nilai personal dapat mempengaruhi persepsi seseorang. Oleh karena itu, pengetahuan mengenai sistem nilai seorang individu bisa memberi pandangan tentang apa yang menjadi motif seseorang (Robbins \& Judge, 2008). Selain itu, Robbins \& Judge, (2008) juga mengemukakan bahwa persepsi adalah proses di mana inidvidu mengatur dan menginterpretasikan kesankesan sensoris mereka guna memberikan arti bagi lingkungan mereka, sehingga apa yang diterima seseorang pada dasarnya bisa diartikan berbeda dari yang lainnya. Berdasarkan uraian diatas, maka penelitian ini ingin menganalisis pengaruh nilai-nilai personal terhadap persepsi dukungan organisasi pada guru - guru Sekolah Menengah Pertama di salah satu lingkungan Yayasan Pendidikan Islam yang ada di Surabaya.

\section{METODE}

\section{Subjek}

Subyek penelitian ini menggunakan adalah guru-guru sekolah menengah pertama 
berjumlah 55 orang yang bekerja dalam lingkungan Yayasan Pendidikan Islam di Surabaya dengan karakteristik memiliki pendidikan minimal S1 serta masa kerja minimal 2 tahun.

\section{Desain Penelitian}

Penelitian ini merupakan studi korelasi yang menggunakan pendekatan kuantitatif, dimana peneliti melakukan survey ke lapangan untuk mengumpulkan data dari subyek penelitian.

\section{Teknik Pengumpulan Data}

Teknik pengumpulan data menggunakan kuesioner. Ada 2 jenis kuesioner, yaitu kuesioner personal values PVQ dari Schwartz (2001) yang diadaptasi oleh Suhariadi (2002) ada 40 item. Kuesioner personal values (PVQ) digunakan untuk mengukur nilai-nilai personal yang terdiri dari nilai personal self direction, nilai personal stimulation, nilai personal hedonism, nilai personal security, nilai personal conformity, nilai personal tradition, nilai personal achievement, nilai personal power, nilai personal benevolence dan nilai personal universalism. Kuesioner persepsi dukungan organisasi menggunakan konsep dari Rhoades \& Eisenberger (2002) yang terdiri dari 17 item yang sudah diadaptasi peneliti sesuai kondisi responden. Masing-masing pernyataan pada kuesioner ada 7 pilihan alternatif jawaban. Metode pengukurannya adalah Self rating, dimana responden memberikan tanggapan dengan memilih satu alternatif jawaban diantara jawaban yang ada.

\section{Teknik Analisa Data}

Perhitungan statistik yang digunakan untuk pengujian pada hipotesis penelitian adalah analisis regresi berganda (multiple regression analysis) dengan bantuan SPSS versi 20.0.

\section{HASIL DAN PEMBAHASAN}

Penelitian ini dilaksanakan pada bulan November 2013. Jumlah subyek penelitian adalah 55 orang guru-guru Sekolah Menengah Pertama Swasta yang bekerja dalam lingkungan salah satu Yayasan Pendidikan Islam di Surabaya.

Tabel 1. Tabel Analisis Regresi

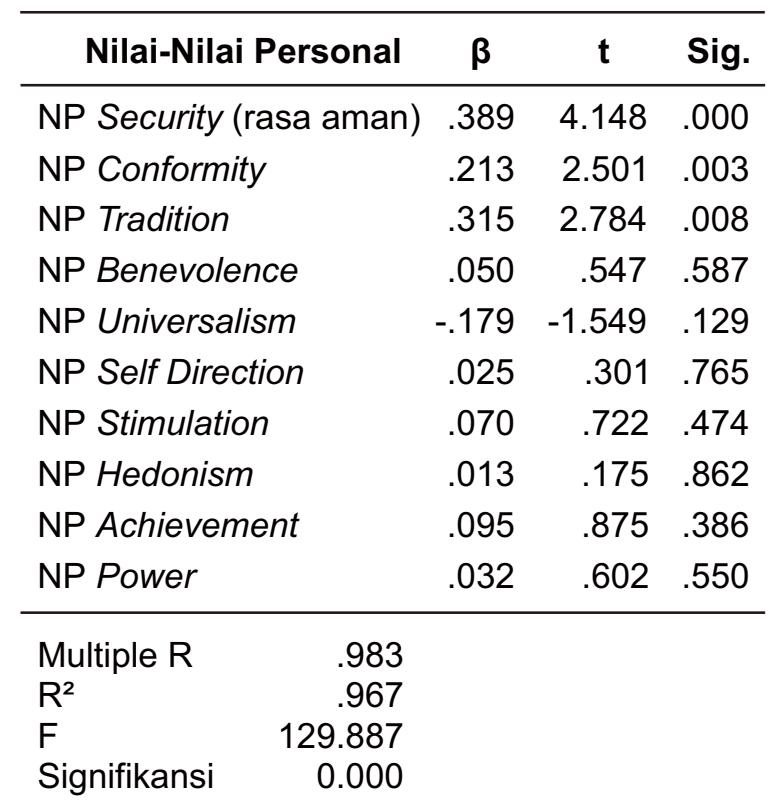

Berdasarkan hasil analisis regresi dapat diketahui bahwa proporsi persepsi dukungan organisasi total yang diterangkan oleh nilainilai personal secara bersama-sama adalah sebesar 96,7\%. Selebihnya (3.3\%) disebabkan oleh variabel-variabel lain.

Secara detail dapat dijelaskan bahwa hasil nilai personal security (rasa aman) memberikan nilai beta sebesar 0,389 dengan nilai signifikansi 0,000 . Bila dibandingkan dengan tingkat signifikansi yang digunakan $\alpha=0,05$ maka lebih kecil sehingga menunjukkan bahwa nilai personal security (rasa aman) memiliki pengaruh yang signifikan terhadap persepsi dukungan organisasi. Dengan demikian dapat disimpulkan bahwa nilai personal security mempengaruhi persepsi dukungan organisasi. 
Sementara nilai personal conformity menunjukkan nilai beta sebesar 0,213 dengan nilai signifikansi 0,003 yang menunjukkan nilai yang lebih kecil dibanding tingkat signifikansi yang digunakan $\alpha=0,05$. Hal ini menunjukkan bahwa nilai personal conformity memiliki pengaruh yang signifikan terhadap persepsi dukungan organisasi. Dengan demikian dapat disimpulkan bahwa nilai personal conformity mempengaruhi persepsi dukungan organisasi.

Sedangkan nilai personal tradition menghasilkan nilai beta sebesar 0,315 dengan nilai signifikansi 0.008 lebih kecil dibanding tingkat signifikansi yang digunakan $\alpha=0,05$. Hal ini menunjukkan bahwa nilai personal tradition memiliki pengaruh yang signifikan terhadap persepsi dukungan organisasi. Dengan demikian dapat dikatakan bahwa nilai personal tradition mempengaruhi persepsi dukungan organisasi.

Nilai personal benevolence menunjukkan hasil nilai beta sebesar 0,050 dengan nilai signifikansi 0,587 lebih besar dibanding tingkat signifikansi yang digunakan $\alpha=0,05$. Hal ini menunjukkan bahwa nilai personal benevolence tidak memiliki pengaruh yang signifikan terhadap persepsi dukungan organisasi. Dengan demikian dapat dikatakan bahwa nilai personal benevolence tidak mempengaruhi persepsi dukungan organisasi.

Nilai personal universalism dapat dilihat nilai beta sebesar 0,179 (negatif) dengan nilai signifikansi 0,129 lebih besar dibanding tingkat signifikansi yang digunakan $\alpha=0,05$. Hal ini menunjukkan bahwa nilai personal universalism tidak memiliki pengaruh yang signifikan terhadap persepsi dukungan organisasi. Dengan demikian, dapat dikatakan bahwa nilai personal universalism tidak mempengaruhi persepsi dukungan organisasi.

Nilai personal self direction menunjukkan nilai beta sebesar 0,025 dengan nilai signifikansi 0,765 lebih besar dibanding tingkat signifikansi yang digunakan $\alpha=0,05$. Hal ini menunjukkan bahwa nilai personal self direction tidak memiliki pengaruh yang signifikan terhadap persepsi dukungan organisasi. Dengan demikian, dapat dikatakan bahwa nilai personal self direction tidak mempengaruhi persepsi dukungan organisasi.

Nilai personal stimulation dapat dilihat nilai beta sebesar 0,070 dengan nilai signifikansi 0,474 lebih besar dibanding tingkat signifikansi yang digunakan $\alpha=0,05$. Hal ini menunjukkan bahwa nilai personal stimulation tidak memiliki pengaruh yang signifikan terhadap persepsi dukungan organisasi. Dengan demikian, dapat dikatakan bahwa nilai personal stimulation tidak mempengaruhi persepsi dukungan organisasi.

Nilai personal hedonism dapat di lihat nilai beta sebesar 0,013 dengan nilai signifikansi 0,862 lebih besar dibanding tingkat signifikansi yang digunakan $\alpha=0,05$. Hal ini menunjukkan bahwa nilai personal hedonism tidak memiliki pengaruh yang signifikan terhadap persepsi dukungan organisasi. Dengan demikian, dapat dikatakan bahwa nilai personal hedonism tidak mempengaruhi persepsi dukungan organisasi.

Nilai personal achievement dapat dilihat nilai beta sebesar 0,095 dengan nilai signifikansi 0,386 lebih besar dibanding tingkat signifikansi yang digunakan $\alpha=0,05$. Hal ini menunjukkan bahwa nilai personal achievement tidak memiliki pengaruh yang signifikan terhadap persepsi dukungan organisasi. Dengan demikian, dapat dikatakan bahwa nilai personal achievement tidak mempengaruhi persepsi dukungan organisasi.

Nilai personal power menunjukkan nilai beta sebesar 0,032 dengan nilai signifikansi 0,550 lebih besar dibanding tingkat signifikansi yang digunakan $\alpha=0,05$. Hal ini menunjukkan bahwa nilai personal power tidak memiliki pengaruh yang signifikan terhadap persepsi dukungan organisasi.

Berdasarkan hasil analisa diatas, maka 
dapat diperoleh gambaran bahwa dari seluruh nilai-nilai personal yang berjumlah sepuluh yang terdiri dari self direction, stimulation, hedonism, security, conformity, tradition, achievement, power, benevolence dan universalism hanya tiga nilai personal yang menunjukkan dapat mempengaruhi persepsi dukungan organisasi yaitu security, conformity, tradition. Nilai personal security dapat mempengaruhi persepsi dukungan organisasi karena guru-guru yang bekerja di lingkungan Yayasan Pendidikan Islam memiliki rasa aman dengan pekerjaannya secara khusus mementingkan dalam hal keselamatan, keselarasan, stabilitas diri, stabilitas kesehatan dan stabilitas hubungan. Oleh karena itu, guru-guru yang memiliki security mempersepsi sudah mendapat dukungan organisasi sekolah yang sesuai harapan mereka.

Sementara guru-guru yang memiliki nilai personal conformity memiliki pengendalian diri yang baik sehingga mampu melakukan kontrol terhadap kemauan dan dorongan yang diluar kebiasaan khususnya dalam hal ketaatan, sopan santun, kepatuhan dan dapat melakukan kontrol diri. Guru-guru yang memiliki conformity mampu melakukan pengendalian diri sehingga mempersepsi berbagai dukungan sekolah yang telah diterimanya sudah dianggap sesuai dengan harapan.

Pada guru-guru yang memiliki nilai personal tradition digambarkan sebagai individu yang memiliki penerimaan diri, penerimaan budaya atau agama, penerimaan adat istiadat atau tradisi dan memiliki rasa hormat pada orang lain. sehingga guru-guru yang mempersepsi baik terhadap dukungan organisasi sekolah tempatnya bekerja.

Hasil penelitian ini menunjukkan bahwa nlai-nilai personal security, conformity, tradition mempengaruhi persepsi dukungan organisasi juga tidak terlepas dari kondisi sekolah tempat guru-guru Sekolah
Menengah Pertama bekerja, dimana sekolah tersebut adalah sekolah yang berada pada lingkup Yayasan Pendidikan Islam yang sudah lama berdiri dan menanamkan nilainilai keagamaan yang kuat serta tradisi yang memegang teguh pada norma sosial yang berlaku dan diterapkan pihak manajemen sekolah dalam kegiatan sehari-hari di lingkungan sekolah. Hal ini membuat guruguru yang bekerja di lingkup Yayasan Pendidikan Islam menjadi terbiasa dengan kondisi tersebut. Guru-guru juga menerapkan nilai-nilai keagamaan dan norma sosial yang berlaku di sekolah tersebut sehingga mereka mampu melakukan pengendalian diri dan mengikuti tradisi yang sudah lama berlaku di sekolah tempatnya bekerja.

Selain itu, guru-guru pada penelitian ini sudah memiliki masa kerja minimal dua tahun sehingga mereka sudah mengetahui dan memahami kondisi sekolah. Hal ini membuat guru-guru menjadi terbiasa dan sudah merasa aman berada di sekolah tempatnya bekerja sehingga guru-guru memberikan persepsi yang baik terhadap dukungan organisasi sekolah.

\section{SIMPULAN DAN SARAN}

Dalam penelitian ini, dapat disimpulkan bahwa nilai-nilai personal yang dapat mempengaruhi persepsi dukungan organisasi adalah nilai personal security (rasa aman), nilai personal conformity, dan nilai personal tradition. Lebih lanjut dapat dijelaskan bahwa nilai personal security (rasa aman) adalah perasaan aman, harmoni, dan stabilitas sosial, dalam hubungan pergaulan sosial dan individu. Oleh karena itu dapat dikatakan bahwa seorang guru yang memiliki nilai personal security memiliki perasaan aman, harmoni dan stabilitas sosial dalam hubungan pergaulan sosialnya sehingga adanya rasa aman yang dimiliki membuat guru merasa bahwa organisasi sekolah telah memberikan 
dukungan atas kontribusi yang telah dilakukan guru-gurunya.

Sementara nilai personal conformity digambarkan sebagai pengendalian diri terhadap kemauan dan dorongan untuk menyakiti orang lain dan melanggar normanorma sosial yang berlaku. Oleh karena itu, seorang guru yang memiliki nilai personal conformity akan mempunyai pengendalian diri terhadap kemauan dan dorongan untuk menyakiti orang lain dan melanggar norma yang berlaku sehingga dengan pengendalian diri yang dimiliki membuat guru-guru tersebut sudah merasakan organisasi sekolah telah memberikan dukungan atas kontribusi yang telah dilakukan guru-gurunya.

Nilai personal tradition dapat disebut sebagai rasa hormat, penerimaan diri dan penerimaan norma-norma budaya, agama dan adat istiadat atau tradisi yang dianutnya. Oleh karena itu, guru yang memiliki nilai personal tradition akan memiliki rasa hormat, keterikatan dan penerimaan akan nilai-nilai budaya dan nilai agama yang kuat sehingga organisasi sekolah memberikan dukungan kepada guru-gurunya karena adanya rasa hormat dan keterikatan yang kuat guru terhadap nilai-nilai budaya dan agama yang dianutnya.

Berdasarkan hasil penelitian ini maka variabel nilai-nilai personal yang tidak berpengaruh signifikan terhadap persepsi dukungan organisasi, antara lain adalah nilai personal benevolence, nilai personal universalism, nilai personal self direction, nilai personal stimulation, nilai personal hedonism, nilai personal achievement, dan nilai personal power.

Penelitian ini mengandung keterbatasan yang patut dipertimbangkan, yaitu penelitian ini hanya dilakukan pada satu sekolah menengah pertama yang berada pada salah satu Yayasan Pendidikan Islam yang ada di Surabaya yang menekankan pada nilai-nilai keagamaan dengan jumlah yang kecil. Oleh karena itu, hasil penelitian ini tidak dapat digeneralisasikan secara luas melainkan terbatas pada guru-guru sekolah menengah pertama yang menjadi subyek penelitian ini.

Penelitian ini bisa dianggap sebagai kajian pendahuluan dan bisa dilanjutkan menjadi penelitian pengembangan sebab penelitian tentang persepsi dukungan organisasi pada guru sekolah menengah pertama yang sepengetahuan peneliti belum banyak dilakukan di Indonesia. Meskipun penelitian ini memiliki beberapa keterbatasan akan tetapi penelitian ini telah berkontribusi terhadap pemahaman dan penjelasan terhadap persepsi dukungan organisasi guru sekolah menengah pertama ditinjau dari nilai-nilai personal khususnya dalam bidang perilaku organisasi dan psikologi yang diharapkan dapat bermanfaat secara teoritik maupun praktis.

Hasil temuan penelitian ini menunjukkan bahwa 1) nilai-nilai personal berpengaruh signifikan terhadap persepsi dukungan organisasi guru-guru di sekolah menengah pertama; 2) nilai personal security (rasa aman), nilai personal conformity, dan nilai personal traditon memiliki pengaruh terhadap persepsi dukungan organsiasi.

Berdasarkan hasil penelitian dan pembahasan di atas dapat dipertimbangkan saran-saran sebagai berikut:1) Bagi peneliti lain yang tertarik dengan permasalahan yang sama, diharapkan untuk melakukan penelitian dengan melibatkan jumlah subyek penelitian yang lebih besar dengan teknik pengambil sampel yang lebih banyak jumlahnya misal menggunakan teknik cluster sampling maupun sensus; 2) Selain itu, juga disarankan untuk melibatkan faktor-faktor demografi yang belum dilihat pada penelitian ini; 3) Penelitian ini dapat dilanjutkan dengan teknik analisis yang berbeda misalnya analisis jalur yang lebih komprehensif, misalnya PLS. 


\section{Daftar Pustaka}

Byrne, Z. S., Wayne A., \& Hochwarter, (2008). Perceived organizational support and performance: Relationships across levels of organizational cynicism, Journal of Managerial Psychology, Vol. 23 Iss: 1, pp. $54-72$

Cropanzano, R., \& Mitchell, M. S. (2005). Social exchange theory: An interdisciplinary review. Journal of Management, 31: 874-900.

Diener, E., Scollon, C. N., \& Lucas, R. E. (2004). The evolving concept of subjective wellbeing: The multifaceted nature of happiness. In P. T. Costa \& I. C. Siegler (Eds.), Advances in cell aging and gerontology, Vol. 15: 187-220. Amsterdam, Netherlands: Elsevier.

Erdogan, B., Kraimer, M. L., \& Liden, R. C., et al. (2004). Work value congruence and intrinsic career success: The compensatory roles of leader-member exchange and perceived organizational support. Journal Personnel Psychology, 57: 305-332.

Klein, H. J., Becker, T. E., \& Meyer, J. P. (2009). Commitment in organizations: Accumulated wisdom and new directions. New York: Routledge/Taylor \& Francis Group.

Lavelle, J. J., Rupp, D. E., \& Brockner, J. (2007). Taking a multifoci approach to the study of justice, social exchange, and citizenship behavior: The target similarity model. Journal of Management, 33: 841-866.

Rhoades, L., \& Eisenberger, R. (2002). Perceived organizational support: A review of the literature. Journal of Applied Psychology, 87, 4: 698-714.
Robbins,S.P \& Judge, T.A (2008) Perilaku Organisasi. Jakarta : Salemba Empat.

Schwartz, S. H. (1992). Universals in The Content and Structure of Values: Theoretical Advanes and Empirical Tests in 20 Contries. Advance in Experimental Social Psychology, 25, 1-65.

Schwartz, S. H. \& Sagiv, L. (1995). Identifying Culture-Specifics in the Content and Structure of Values, Journal of Cross Cultural Psychology, 26: 92-116.

Schwartz, S. H. (2001). Value Hierarchies Across Cultures: Taking a Similarities Perspective. Journal of Cross Cultural Psychology, 32 : 268-290.

Schwartz, S. H. (2012). An Overview of the Schwartz Theory of Basic Values. International Association for Cross Cultural Psychology. doi: 10.9707/23070919.1116.

Shore, L. M., Tetrick, L. E., Lynch, P., \& Barksdale, K., et al. (2006). Social and economic exchange: Construct development and validation. Journal of Applied Social Psychology, 36: 837-867.

Suhariadi, F. (2002). Pengaruh Variabel-Variabel Individu Dan Organisasi Terhadap Semangat Penyempurnaan Dalam Membentuk Perilaku Produktif. Disertasi Institut Teknologi Bandung, tidak diterbitkan. 